\title{
Upaya Peningkatan Kemampuan Berpikir Kritis dan Hasil Belajar Melalui Model Pembelajaran Cooperative Learning Tipe Jigsaw
}

\author{
Avita Widia Sari ${ }^{*}$, Stefanus C. Relmasira ${ }^{2}$, Agustina Tyas Asri Hardini ${ }^{3}$ \\ 1,2,3 Fakultas Keguruan dan Ilmu Pendidikan Program Studi Pendidikan Guru Sekolah Dasar, Universitas Kristen Satya Wacana, Salatiga
}

A R T I C L E I N F O

Article history:

Received 20 February 2019

Received in revised form

10 March 2019

Accepted 24 April 2019

Available online 20 May 2019

Kata Kunci:

Berpikir Kritis, Hasil

Belajar, Pembelajaran

Kooperatif tipe Jigsaw

Keywords:

Critical Thinking, Result of

Learning, Cooperative

Learning type Jigsaw.

\begin{abstract}
A B S T R A K
Penelitian ini bertujuan untuk meningkatkan kemampuan berpikir kritis dan hasil belajar siswa melalui model pembelajaran Cooperative Learning Tipe Jigsaw,pada mata pelajaran tematik tema 6 panas dan perpindahanya pada kelas V semester II. Penelitian ini merupakan penelitian tindakan kelas dengan menggunakan pendekatan kualitatif dan kuantitatif. Data penelitian diperoleh melalui wawancara, non tes (observasi), tes, dan studi dokumen. Subjek penelitian adalah siswa kelas V SD Negeri Noborejo 01 Kecamatan Argomulyo Kota Salatiga sebanyak 39 siswa. Prosedur kegiatan meliputi empat tahapan yaitu perencanaan, pelaksanaan, observasi, refleksi melalui dua siklus pembelajaran, terdapat refleksi pada tindakan siklus I kemudian dilakukan perbaikan pada tindakan siklus II, setiap siklus terdiri dari 3 pertemuan. Pada siklus I persentase kemampuan berpikir kritis siswa $87 \%$, kemudian meningkat menjadi $97 \%$ pada siklus II. Peningkatan kemampuan berpikir kritis siswa juga berdampak pada hasil belajar siswa, dimana siklus I jumlah ketercapaian hanya $80 \%$ dari jumlah siswa meningkat menjadi $94 \%$ pada siklus II. Hasil penelitian menunjukan bahwa dengan penerapan langkah-langkah model pembelajaran Cooperative Learning Tipe Jigsaw dapat meningkatkan kemampuan berpikir kritis dan hasil belajar pada pembelajaran tematik tema 6 panas dan perpindahanya siswaV SD Negeri Noborejo 01.
\end{abstract}

A B S T R A C T

The study aims to improve students'critical thinking and the result of students learning through Cooperative Learning Type Jigsaw, especially fifth grade of students. The study focused on thematic subject, theme 6 entitled "Panas dan Perpindahannya". The research used both method, qualitative and quantitative. Then the data was got by interview, observation and documentation. Moreover, the participants were one 39 students. There are 4 procedures to get the data from the research; (1) Planning, (2) Implementation and (3) Observation (4) The reflection also used to the research since to add accuracy of the research. The reflection passed through two cycle of learning. There are reflections the actions in cycle I then improvements are made to the actions the second in cycle II, each cyle consist of three meetings. In the first cycle the percentage of students' critical thinking skills was $87 \%$, then increased to $97 \%$ in cycle II. Increasing students' critical thinking skills also has an impact on student learning outcomes, where the first cycle of the number of achievements is only $80 \%$ of the number of students increased to $94 \%$ in the second cycle. The results showed that the application of the steps of the Cooperative Learning type Jigsaw model can improve critical thinking skills and learning outcomes in hot theme 6 entitled "Panas dan Perpindahannya"transfer of students to SD Negeri Noborejo $01 .$. 


\section{Pendahuluan}

Kurikulum 2013 dilihat dari sisi tujuan berbasis pada 4C yaitu communication, collaboration, critical thinking dan creativity, merupakan kemampuan sesungguhnya yang ingin dituju dengan kurikulum 2013. Rumusan kompetensi dalam kurikulum ini didasarkan pada perpaduan ketiga ranah belajar, yakni ranah sikap dan perilaku yang diwarnai nilai-nilai agama dan sosial kultural, ranah pengetahuan, dan ranah psikomotor (Sundayana, 2014:25).

Hasil belajar adalah ukuran atau tingkatan keberhasilan yang dicapai oleh seorang peserta didik berdasarkan pengalaman yang diperoleh setelah dilakukan evaluasi berupa tes dan biasanya diwujudkan dengan nilai atau angka-angka tertentu serta menyebabkan terjadinya perubahan kognitif, efektif, maupun psikomotorik Sudjana (2010:22).

Menurut Nitko \& Brookhart (2011:236) kemampuan berpikir kritis dinilai dan diukur dalam konteks pembelajaran tertentu, bukan secara umum. Berpikir kritis adalah proses yang melibatkan operasi mental seperti induksi, deduksi, klasifikasi, dan penalaran (Ariawan, 2014). Dalam proses berpikir terdapat juga didalamnya kegiatan meragukan, memastikan, merancang, menghitung, mengukur, mengevaluasi, membandingkan, mengelompokkan, menggolongkaln, memilahmilah, membedakan, menafsir, melihat kemungkinan yang ada, menganalisis dan sintesis, menalar dan menarik kesimpulan, menimbang, dan memutuskan" (Maulana, 2017). Berpikir kritis menuntut upaya keras untuk memeriksa keyakinan atau pengetahuan asumtif berdasarkan bukti pendukungnya dan kesimpulan-kesimpulan lanjutan yang diakibatnya, untuk itu, guru perlu memasukkan indikator-indikator untuk kemampuan berpikir kritis ke dalam konteks materi pembelajaran, selanjutnya materi pembelajaran dihubungkan dengan kondisi kehidupan sehari-hari. Menurut Wijayanti (2018) dalam berpikir kritis siswa mampu mengenali permaslahan yang dihadapi dan tau bagaimana harus menyelesaikannya.

Berdasarkan hasil observasi di kelas dan wawancara dengan guru kelas V SD Negeri Noborejo 01, pada tanggal 18 September 2018 didapatkan proses belajar dan mengajar guru masih menggunakan model konvensional, guru juga masih menggunakan metode ceramah dan pada saat pembelajaran berlangsung guru kurang interaktif dalam memberikan kesempatan siswa untuk bertanya seputar pelajaran yang dibahas, sehingga peserta didik kurang mampu untuk meningkatkan kemampuan berpikir kritis, agar siswa dapat memanipulasi informasi yang diberikan oleh guru dan ide-ide dengan cara tertentu, dalam pembelajaran dikelas guru menjelaskan materi dengan tanya jawab, lalu guru memberikan soal evaluasi kepada peserta didik. Hasil belajar peserta didik kurang memenuhi KKM yang di tentukan oleh sekolah SD Negeri Noborejo 01 yaitu 70. Observasi yang dilakukan peneliti pada pra siklus menunjukan bahwa hasil belajar masih rendah, hal ini didukung dengan data dari 39 siswa terdapat 30 siswa yang sudah mencapai KKM 70, sedangkan 9 siswa belum mencapai KKM 70, dalam proses pembelajaran baik penggunaan penggunaan metode ceramah belum mampu meningkatkan kemampuan berpikir kritis dan hasil belajar peseta didik, sehingga dibutuhkan pembelajaran yang membangkitkan kemampuan bepikir kritis peserta didik.

Dari hasil pengamatan secara keseluruhan, Peserta didik kurang fokus dalam menentukan gagasan pokok atau masalah utama dalam pembelajaran, peserta didik belum mengerti materi yang di jelaskan oleh guru sehingga peserta didik di dalam mengerjakan soal evaluasi masih sering bertanya apa arti dari soal tersebut, selain itu peserta didik sulit untuk memahami dan menganalisis materi yang disajikan oleh guru, karena yang mereka rasakan pembelajaran yang di sampaikan oleh guru kurang bermakna, dan sulit sekali mereka pahami, sehingga peserta didik tidak dapat menyimpulkan argument yang telah disajikan, peserta didik juga sering sekali susah dalam menentukan bagian yang dapat dipertimbangkan, untuk dapat di percaya atau tidak dipercaya, serta peserta didik masih sulit untuk memberikan alasan, apabila guru mengajukan pertanyaan karena takut salah dan kurangnya kemampuan berpikir kritis.

Peserta didik juga belum mampu untuk membuat kesimpulan secara deduktif hal ini, terjadi karena peserta didik kurang mencerna materi yang di maksud oleh guru dan kurang berlatih untuk memahami materi yang di sampaikan oleh guru, serta belum mampu membuat kesimpulan secara induktif yang telah disajikan oleh guru di dalam sebuah pertanyaan, dan belum mampu untuk memberikan alasanya. Peserta didik juga masih bingung dalam menentukan sebuah solusi yang tepat, ada yang positif dan negatif, solusi mana yang paling tepat untuk memecahkan masalah yang telah disajikan oleh guru. Sehingga peserta didik belum mampu untuk mengambil keputusan dalam tindakan penyelesaian masalah, sehingga kurangnya kemampuan berpikir kritis dan hasil belajar peserta didik.

Berdasarkan masalah yang ditemukan, salah satu model yang dapat digunakan untuk meningkatkan siswa dalam berpikir kritis dan hasil belajar dalam memahami konsep materi pembelajaran, yaitu model pembelajaran yang interaktif yakni model Cooperative Learning Tipe Jigsaw. Menurut Slavin (Rusman, 2010:201) pembelajaran Cooperative Learning Tipe Jigsaw menggalakkan siswa berinteraksi secara aktif dan positif dalam kelompok dan membolehkan pertukaran ide sendiri dalam 
suasana yang tidak terancam, sesuai dengan falsafah konstruktivisme. Teknik Jigsaw memungkinkan siswa untuk berpartisipasi secara aktif dalam proses pembelajaran (Khusniyah, 2014). Penelitian relevan yang pernah dilakukan oleh Ni Luh Adhe Yanti Lestari, I Gusti Agung Oka Negara dan Siti Zulaikha (2014) dengan judul pengaruh model pembelajaran kooperatif tipe Jigsaw terhadap hsil belajar siswa kelas V SD Gugus I Kuta Badung. Menunjukkan bahwa terdapat perbedaan yang signifikan terhadap hasil belajar IPA antara siswa yang belajar melalui model kooperatif tipe Jigsaw dengan siswa yang belajar menggunakan model konvensional, khususnya pada siswa kelas V SD Gugus I Kuta Badung. Penelitian yang dilakukan oleh Olyn Suyanti Darmada, Semara Putra, dan I. Gd. Meter (2013) menunjukkan model pembelajaran kooperatif tipe Jigsaw lebih memberikan pengaruh terhadap hasil belajar IPS di SDN 2 Rendang. Penelitian oleh Faozi (2018) bahwa penerapan Model Pembelajaran Kooperatif Tipe Jigsaw dapat meningkatkan aktivitas dan hasil belajar Biologi pada pokok bahasan Bioteknologi pada siswa kelas IXA SMP Negeri 2 Tarub Tahun Pelajaran 2017/ 2018.

Dalam pembelajaran Cooperative Learning Tipe Jigsaw siswa belajar dalam kelompok sehingga, mereka dapat menukarkan pengetahuan serta mencari pengetahuan baru dari sumber lain, sama halnya dengan High Order Thinking Skills (HOTS) merupakan, suatu proses berpikir peserta didik dalam level kognitif yang lebih tinggi yang telah dikembangkan dari berbagai konsep, metode, kognitif dan pembelajaran seperti taksonomi bloom (Saputra, 2016:91).

Tujuan utama dari High Order Thinking Skills adalah bagaimana meningkatkan kemampuan berpikir peserta didik, terutama berkaitan dengan kemampuan berpikir kritis tingkat tinggi. Sehingga terdapat keterkaitannya dengan model pembelajaran Cooperative Learning Tipe Jigsaw, melalui model pembelajaran tersebut, peserta didik termotivasi untuk mempelajari materi dengan baik dan bekerja keras sehingga peserta didik dapat berpikir kritis dan meningkatkan hasil belajar dengan baik.

\section{Metode}

Penelitian ini merupakan jenis Penelitian Tindakan Kelas (PTK). Penelitian Tindakan Kelas atau PTK (Classroom Action Research), di dalam penelitian ini menggunkan empat tahapan yaitu: (1) perencanaan, (2) pelaksanaan tindakan, (3) observasi. (4) refleksi. Penelitian ini dibantu oleh guru guna mengobservasi kegiatan pada saat proses pembelajaran berlangsung. Penelitian ini dilaksanakan dengan dua siklus. Setiap siklus terdiri dari tiga kali pertemuan, pada siklus I dilaksanakan pada tanggal 16-19 Maret 2019, dan siklus II dilaksanakan pada tanggal 20-22 Maret 2019, dengan alokasi waktu 3x35 menit setiap pertemuannya.

Teknik pengumpulan data yang digunakan penelitian tindakan kelas ini ada 3 yaitu teknik pengumpulan data non tes, teknik pengumpulan data tes. Jenis data dan metode studi dokumen, teknik pengumpulan data berupa tes tertulis dengan bentuk pilihan ganda dan uraian, digunakan untuk mengukur hasil belajar Bahasa Indonesia dan IPA siswa pada pembelajaran tematik tema 6 panas dan perpindahanya subtema 1 dan 2, lembar observasi diisi oleh observer digunakan untuk mengukur kemampuan berpikir kritis siswa pada saat proses pembelajaran berlangsung, dan studi dokumen digunakan peneliti untuk menyelidiki benda-benda tertulis seperti buku-buku majalah, dokumen, gambargambar, notulen rapat, dan catatan harian.

Indikator keberhasilan dalam penelitian ini dibagi menjadi dua yaitu: (1) indikator proses dimana keberhasilan yang akan peneliti capai $100 \%$ dari sintaks model pembelajaran Cooperative Learning Tipe Jigsaw dengan urut dan sistematis, dapat dilihat dari peningkatan dalam proses pembelajaran tematik pada tema 6 panas dan perpindahanya, pada muatan Bahasa Indonesia dan IPA, (2) indikator hasil, indikator hasil kemamapuan berpikir kritis menggunakan lembar observasi yang telah diolah, sehingga dapat diketahui adanya peningkatan, sedangkan hasil belajar siswa menggunakan soal evaluasi siklus I dan II. Hasil dari setiap siklus digunakan untuk mengetahuai peningkatan hasil belajar siswa. Indikator yang digunakan adalah kriteria ketuntasan minimal (KKM). Hasil pembelajaran tematik pada muatan Bahasa Indonesia dan IPA meningkat apabila diatas 80\% dari jumlah siswa memperoleh nilai diatas KKM 70.

\section{Hasil dan Pembahasan}

Berdasarkan hasil penelitian menggunakan model pembelajaran Cooperative Learning Tipe Jigsaw terdapat, perbandingan hasil dari penilaian kemampuan berpikir kritis dan hasil belajar sisiwa dari pelaksanaan pra siklus, siklus I dan siklus II dapat dilihat dalam tabel dan diagram dibawah ini: 
Tabel 1. Perbandingan Kemampuan Berpikir Kritis Siswa Pra Siklus, Siklus I, dan Siklus II Kelas V SD Negeri Noborejo 01.

\begin{tabular}{|c|c|c|c|c|}
\hline No & Kategori & Pra Siklus & Siklus I & Siklus II \\
\hline 1 & Sangat Baik & 3 & 5 & 5 \\
\hline 2. & Baik & 7 & 7 & 13 \\
\hline 3. & Cukup & 6 & 22 & 20 \\
\hline 4. & Kurang & 23 & 5 & 1 \\
\hline & inggi & 4 & 4 & 4 \\
\hline & ndah & 1,7 & 1,8 & 1,0 \\
\hline & & 2,7 & 2,8 & 3,0 \\
\hline
\end{tabular}

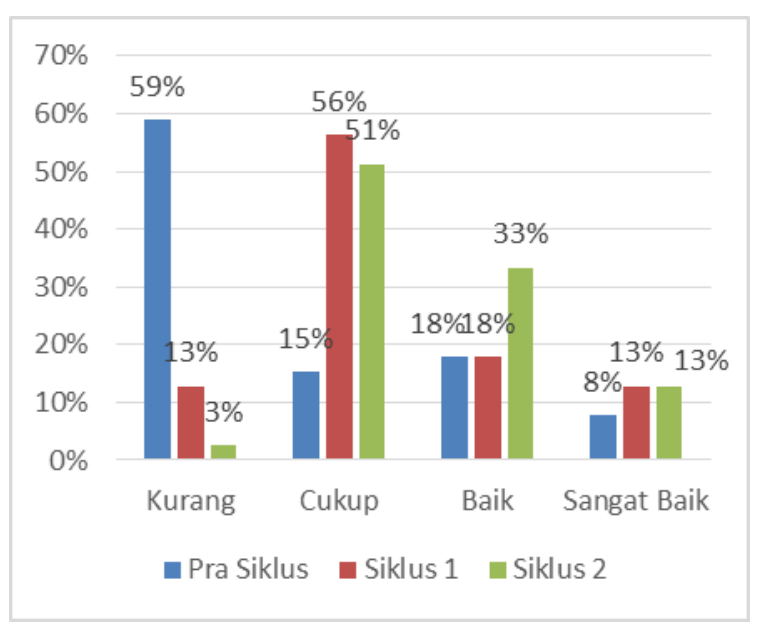

Gambar 1. Grafik Perbandingan Kemampuan Berpikir Kritis Siswa Pra Siklus, Siklus I, dan Siklus II Kelas V SD Negeri Noborejo 01.

Berdasarkan data yang disajikan pada Tabel 1 dan Grafik 1 di atas dapat dilihat bahwa hasil penelitian Kemampuan Berpikir Kritis siswa pada pembelajaran sub tema 6 Panas dan Perpindahanya di kelas V SD Negeri Noborejo 01 dengan model pembelajaran Cooperative Leraning Tipe Jigsaw dari pra siklus, siklus I dan siklus II menunjukan peningkatan.Hal ini dapat ditunjukan dengan kemampuan berpikir kritis siswa pada pra siklus hanya memperoleh rata-rata sebesar 2,7 setelah memperoleh tindakan pada siklus I rata-rata kemampuan berpikir kritis siswa meningkat menjadi 2,8, kemudian terjadi rata-rata peningkatan menjadi 3,0 setelah dilakukan tindakan pada siklus II. Peningkatan kemampuan berpikir kritis siswa juga berdampak dengan hasil belajar pada siswa. Berikut ini adalah perbandingan peningkatan hasil belajara siswa dari pra siklus, siklus I, siklus II dapat dilihat dari tabel dan diagram berikut ini:

Tabel 2. Perbandingan Hasil Belajar Siswa Pra Siklus, Siklus I, dan Siklus II Kelas V SD Negeri Noborejo 01.

\begin{tabular}{|c|c|c|c|c|}
\hline No & Kategori & Pra Siklus & Siklus I & Siklus II \\
\hline 1. & Tuntas & 30 & 32 & 37 \\
\hline 2 & Tidak Tuntas & 9 & 8 & 2 \\
\hline \multicolumn{2}{|c|}{ Nilai Tertinggi } & 96 & 98 & 100 \\
\hline \multicolumn{2}{|c|}{ Nilai Terendah } & 50 & 50 & 60 \\
\hline \multicolumn{2}{|c|}{ Rata-rata } & 75 & 77 & 85 \\
\hline
\end{tabular}




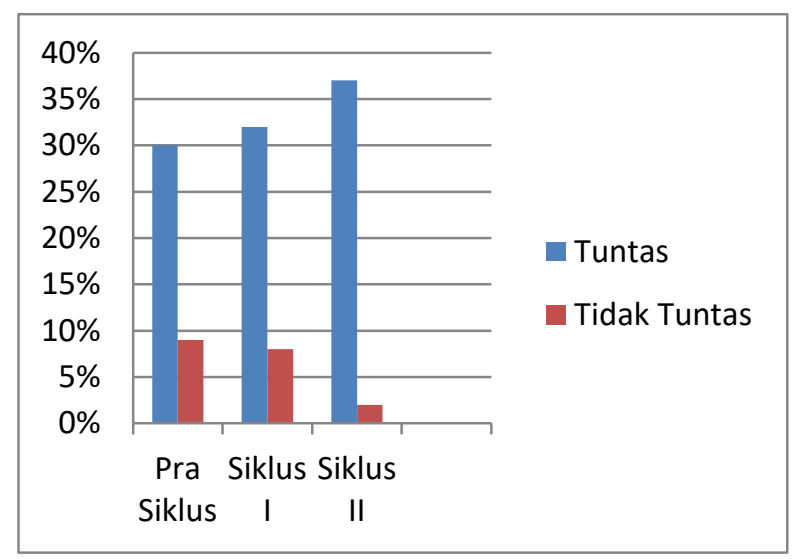

Gambar 2. Grafik Perbandingan Hasil Belajar Siswa Pra Siklus, Siklus I, dan Siklus II Kelas V SD Negeri Noborejo 01.

Berdasarkan data yang disajikan pada tabel dan grafik di a atas dapat dilihat bahwa, hasil belajar siswa pada pembelajaran sub tema 6 Panas dan Perpindahanya di kelas V SD Negeri Noborejo 01 dari pra siklus , siklus I dan siklus II menunjukan peningkatan. Hal ini dapat ditunjukan pada siklus I jumlah siswa yang telah mencapai ketuntasan (70) meningkat menjadi 32 siswa jika dibandingkan dengan pra siklus ketuntasan (70) yang diperoleh 30, kemudian keberhasilan indikator belum tercapai maka di lakukan dengan tindakan pada siklus II dengan hasil peningkatan yang sangat baik. Hal ini dapat dilihat pada siklus II jumlah siswa yang mencapai ketuntasan (70) meningkat menjadi 37 siswa jika di bandingkan dengan pra siklus. bawah ini:

Perbandingan aktivitas guru pada siklus I dan siklus II dapat dilihat dari tabel dan diagram di

Tabel 3 Perbandingan Aktivitas Guru Siklus I dan Siklus II

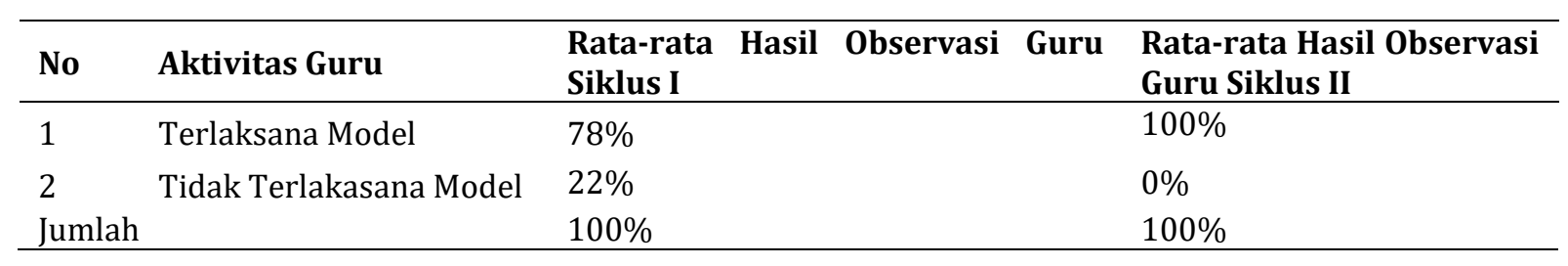

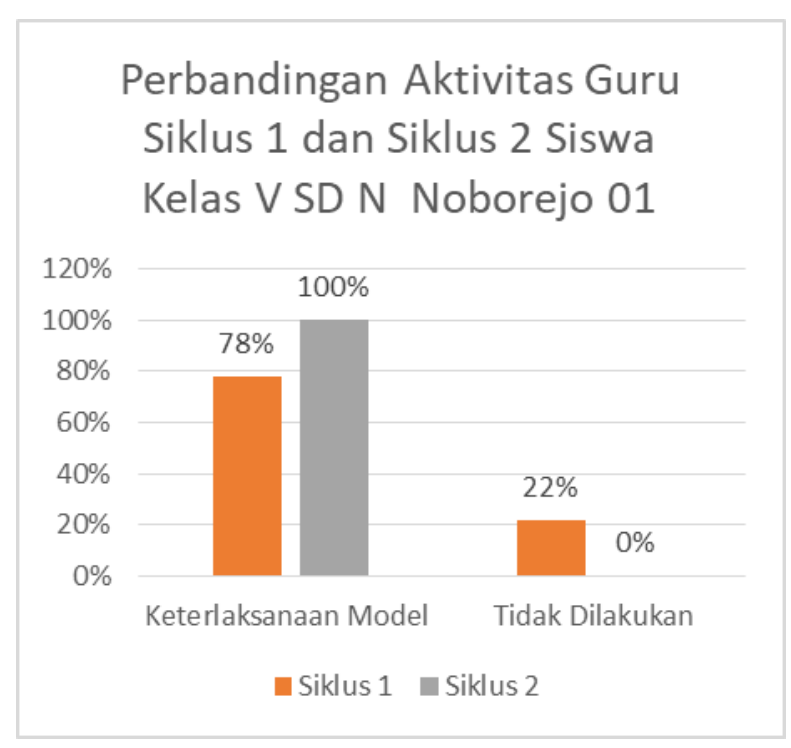

Gambar 3. Grafik Diagaram Perbandingan aktivitas Guru Siklus I dan Siklus II 
Berdasarkan Tabel 3 dan grafik 3 menunjukan bahwa kativitas guru pada siklus I dan siklus II yang masing-masing siklus terdiri dari 3 kali pertemuan memperoleh rata-rata $100 \%$ aktivitas guru masuk kedalam kategori sangat baik.

Hasil penelitian yang dilakukan oleh peneliti pada siswa kelas V SD Negeri Noborejo 01 Salatiga dengan menggunakan model pembelajaran Cooperative Learning Tipe JIGSAW terlihat terjadi peningkatan pada kemampuan berpikir kritis dan hasil belajar siswa, pada pembelajaran tematik tema 6 panas dan perpindahanya mulai dari kondisi awal (pra siklus), siklus I sampai siklus II. Terdapat refleksi tindakan pada siklus I yang dilaksanakan dengan tujuan untuk mengetahui kekurangan yang terdapat pada pelaksanaan siklus I, yaitu (1) Dalam mengaitkan materi dalam pembelajaran masih kurang, (2) Pada saat menyampaikan materi pembelajarn siswa masih banyak yang kurang fokus dan banyak membuat kegaduhan di dalam kelas, (3) Pada saat siswa menyajikan hasil karya dari kelompoknya masing-masing, banyak siswa yang masih tidak memperhatikan kelompok yang sedang presentasi, (4) Dalam berdiskusi kelompok banyak siswa yang membuat kegaduhan sehingga kelompok lain tidak dapat berkonsetrasi untuk membuat hasil karyanya, (5) hanya 9 siswa yang selalu aktif untuk menyajikan karya.

Setelah dilakukan analisis kekurangan-kekurangan tersebut kemudian dilakukan perbaikan untuk guna tindakan pada siklus II, yaitu (1) Dalam mengaitkan materi dalam pembelajaran sudah baik, sehingga siswa dapat lebih memahami tentang materi yang di berikan oleh guru, (2) Pada saat menyampaikan materi pembelajaran susana di dalam kelas sudah konduusif karena guru selalu menegur dan memberi hukuman agar selalu patuh dan mengikuti pembelajaran dengan baik, (3) Pada saat siswa menyajikan hasil karya dari kelompoknya masing-masing, guru selalu memberikan sebuah reward berupa tepuk tangan sehingga kelompok merasa di hargai dan menumbuhkan rasa semangat di dalam diri siswa, (4) Dalam berdiskusi kelompok, guru sebagai fasilitator selalu berkeliling untuk membimbing kelompok belajar, hal tersebut membuat anggota kelompok aktif dan ikut berpartispasi dalam diskusi kelompok tersebut, (5) Dalam kegiatan menyajikan hail diskusi kelompok siswa lebih antusias dan selalu memperhatikan temanya yang sedang menyajikan hasil diskusi dan karyanya tersebut di depan kelas

Peningkatan kemampuan berpikir kritis dilihat dari data hasil observasi yang dilakukan oleh guru pada kondisi awal atau Pra siklus, siklus I dan siklus II. Pada saat Pra siklus sebelum diterapkannnya model pembelajaran Cooperative Learning Tipe Jigsaw rata-rata kemampuan berpikir kritis siswa sebesar 59\% dengan kategori kurang, pada siklus I persentase kemampuan berpikir kritis siswa 87\%, kemudian meningkat menjadi $97 \%$ pada siklus II. Peningkatan kemampuan berpikir kritis siswa juga berdampak pada hasil belajar siswa, dimana siklus I jumlah ketercapaian hanya $80 \%$ dari jumlah siswa meningkat menjadi $94 \%$ pada siklus II.

Berdasarkan uraian diatas maka, penerapan model pembelajaran Kooperative Learning Tipe Jigsaw pada siswa kelas V SD Negeri Noborejo 01 dapat meningkatkan kemampuan berpikir kritis dan hasil belajar pada pembelajaran tematik tema 6 panas dan perpindahanya. Hasil penelitian ini memperkuat penelitian terdahulu seperti yang dilakukan oleh Piasih, Ariyanti, dan Dantes (2013), penelitian milik Sumarno, dan Handayani (2014), Aminah (2017), Wardani (2013). Serta penelitian yang dilakukan oleh Utariasih (2017) yang menyatakan pembelajaran dengan menggunakan model pembelajaran kooperatif tipe jigsaw berbantuan media gambar berpengaruh terhadap hasil belajar IPA siswa kelas V SD di Gugus V Kecamatan Banjar tahun ajaran 2017/2018.

Hal yang membedakan penelitian yang dilakukan ini dibandingkan penelitian sebelumnya yaitu penelitian ini mengukur kemampuan berpikir kritis siswa sekaligus hasil belajar Bahasa Indonesia dan IPA siswa pada pembelajaran tematik tema 6 panas dan perpindahanya dengan menggunakan model pembelajaran Cooperative Learning Tipe Jigsaw. Selain itu dalam penelitian ini bukan hanya aspek kognitif yang dapat terlihat meningkat akan tetapi aspek afektif dan psikomotorik ikut meningkat. Dengan menggunakan model pembelajaran yang berbasis kooperatif maka siswa dituntut untuk belajar dalam kelompok kecil yang terdiri dari 4-5 orang, terdapat kelompok ahli dan kelompok asal sehingga siswa dapat bekerjasama positif dan setiap anggota bertanggung jawab untuk memepelajari masalah tertentu dari materi yang diberikan. Penggunaan model pembelajaran Cooperative Learning Tipe Jigsaw juga dapat memudahkan dan memberikan pengalaman langsung baik bagi siswa maupun guru, sehingga pembelajaran tersebut akan menjadi lebih bermakna sesuai dengan materi yang telah diajarkan pada siswa kelas V SD Negeri Noborejo 01.

\section{Simpulan Dan Saran}

Berdasarkan hasil penelitian yang telah dilaksanakan di SD Negeri Noborejo 01, maka dapat disimpulkan bahwa, hasil penelitian pembelajaran Cooperative Learning Tipe Jigsaw dapat meningkatkan kemampuan berpikir kritis dan hasil belajar, pada pembelajaran tematik tema 6 panas dan perpindahanya siswa kelas V SD Negeri Noborejo 01 Salatiga. Hal tersebut dibuktikan dengan data pada saat pra siklus 
kemampuan berpikir kritis siswa sebesar 59\% dengan kategori kurang, pada siklus I presentase kemampuan berpikir kritis siswa 87\%, kemudian meningkat menjadi $97 \%$ pada siklus II. Peningkatan berpikir kritis siswa juga berdampak dengan hasil belajar siswa, dimana siklus I jumlah ketercapaian hanya $80 \%$, dari jumlah siswa meningkat menjadi $94 \%$ pada siklus II. Hasil penelitian menunjukan bahwa dengan penerapan langkah-langkah model pembelajaran Cooperative Learning Tipe Jigsaw dapat meningkatkan kemampuan berpikir kritis dan hasil belajar pada pembelajaran tematik tema 6 panas dan perpindahanya siswa V SD Negeri Noborejo 01.

\section{Daftar Rujukan}

Afriki, dkk. 2017. Buku Guru Tema 6 "Panas dan Perpindahanya”. Buku Tematik Terpadu Kurikulum 2013 Revisi 2017 Kementrian Pendidikan dan Kebudayaan.

Afriki, dkk. 2017. Buku Peserta didik Tema 6 "Panas dan Perpindahanya". Buku Tematik Terpadu Kurikulum

2013 Revisi 2017. Kementrian Pendidikan dan Kebudayaan.

Aminah, H. S. (2017). Peningkatan Hasil Belajar IPA Melalui Model Kooperatif Tipe Jigsaw Berbantu Media Gambar Kelas IV SDN 04 Jambangan 2016/2017 (Doctoral dissertation, Program Studi Pendidikan Guru Sekolah Dasar FKIP-UKSW).

Ariawan, I Putu Wisna. 2014. PENGEMBANGAN LKM MULTI REPRESENTASI BERBANTUAN GEOGEBRA UNTUK MENINGKATKAN KEMAMPUAN BERPIKIR KRITIS MAHASISWA. Jurnal Pendidikan Indonesia Vol. 3, No. 1

Arikunto, Suharsimi. (2010). Prosedur Penelitian. Jakarta: Rineka Cipta.

Budiawan, Nengah, I Dw. Pt. Raka Rasana, Ni Md. Setuti. 2017. PENGARUH MODEL PEMBELAJARAN KOOPERATIF TIPE JIGSAW II BERBASIS PETA KONSEP TERHADAP HASIL BELAJAR IPS PADA SISWA KELAS IV. Jurnal Mimbar PGSD Universitas Pendidikan Ganesha Volume 3 No 4.

Darmada, Olyn Suyanti, Samara Putra, dan I. Gd. Meter. (2013). Pengaruh Model Pembelajaran Cooperative Learning Tipe Jigsaw terhadap Hasil Belajar IPS Siswa Kelas IV di SDN 1 dan 2 Rendang. Mimbar PGSD Undiksha. 1(1). 1-10.

Endrayanto, H.Y.S. \& Harumurti, Y.W. (2014). Penilaian Belajar Siswa di Sekolah. Daerah Istimewa Yogyakarta: PT KANISIUS.

Faozi, Mohamad. 2018. Penerapan Model Pembelajaran Kooperatif Tipe Jigsaw untuk Meningkatkan Aktivitas dan Hasil Belajar IPA Materi Bioteknologi pada Siswa SMP Negeri 2 Tarub Jurnal Pendidikan MIPA Pancasakti Volume 2 Nomor 1, Januari 2018, (Hal. 11- 15) http://ejournal.ups.ac.id/index.php/jpmp

Fisher, A. (2009). Berpikir Kritis. Jakarta: Erlangga.

Fiyany, Fitria Nur, Mawardi, Suhandi Astuti. 2018. Keefektifan Model Pembelajaran Bamboo Dancing dan Jigsaw Ditinjau Dari Hsail Belajar Matematika Siswa Kelas 4 SD. Jurnal Teori dan Aplikasi Matematika Vol. 2 No. 1, April 2018, Hal. 76-86

Kunandar. (2008). Langkah Mudah Penelitian Tindakan Kelas Sebagai Pengembangan Profesi Guru. Jakarta: PT Raja Grafindo Persada.

Lestari, Ni Luh Adhe Yanti, I Gusti Agung Oka Negara dan Siti Zulaikha. (2014). Model Pembelajaran Kooperatif Tipe Jigsaw Berpengaruh terhadap Hasil Belajar IPA Siswa Kelas V SD Gugus I Kuta Badung. Jurnal Mimbar PGSD Universitas Pendidikan Ganesha.2(1), 1-10 
Dantes, Nyoman. (2013). Pengaruh Model Pembelajaran Kooperatif Tipe Jigsaw Terhadap Kemampuan Berpikir Kritis Dan Prestasi Belajar Siswa Dalam Pembelajaran IPS Pada Siswa Kelas IV SD Cipta Dharma Denpasar (Jurnal Pendidikan Dasar Ganesha).

Khusniyah, Nurul, Nyoman Retug, I Wayan Redhana. 2014. PENGARUH MODEL PEMBELAJARAN KOOPERATIF JIGSAW IV TERHADAP HASIL BELAJAR KIMIA SISWA SMA. Jurnal Wahana Matematika dan Sains, Volume 8 Nomor 1.

Maulana. (2017). Kemampuan Dasar Matematika dan Pengembangan Kemampuan Berpikir Kritis-Kreatif. Sumedang: UPI Sumedang Press

Nitko, A.J. \& Brookhart, S.M. (2011). Educational Assessment of Student (6th ed). Boston: Pearson Education.

Priastuti, R. W. (2013). Penggunaan Model Pembelajaran Jigsaw dengan Percobaan untuk Meningkatkan Hasil Belajar Siswa Kelas 5 SDN Sidorejo Kidul 03 Salatiga Mata Pelajaran IPA Semester II Tahun Pelajaran 2012/2013 (Doctoral dissertation, Program Studi Pendidikan Guru Sekolah Dasar FKIPUKSW).

Slavin, Robert E. (2005). Cooperative learning:teori, riset, dan praktik. Bandung: Nusa Media

Sugiyono. (2015). Metode Penelitian Kuantitatif, Kualitatif, dan R \&D. Bandung: ALFABETA ,CV.

Supratikaya. (2012). Penilaian Hasil Belajar dengan Teknik Nontes. Yogyakarta: Universitas Sunata Darma.

Sumarno. Handayani, S. \& Triyono. (2013). Penerapan Model Pembelajaran Kooperatif Tipe Jigsaw Untuk Meningkatkan Penguasaan Konsep dan Keterampilan Berpikir Kritis Pada Mata Pelajarn IPA SD di kabupaten Blora. (Program Studi Sekolah Dasar Universitas Terbuka).

Uno, H., Lamatenggo, N., Koni, S., (2011). Menjadi Peneliti PTK yang Profesional. Jakarta: Bumi Aksara.

Utariasih, Luh Juli, I Nyoman Jampel, I Nyoman Murda. 2018. PENGARUH JIGSAW BERBANTUAN MEDIA GAMBAR TERHADAP HASIL BELAJAR IPA KELAS V DI SD GUGUS V. Indonesian Journal Of Educational Research and Review, Vol. 1 No. 2.

Widyoko, E.P. (2013). Evaluasi Program Pembelajaran. Yogyakarta: PUSTAKA PELAJAR.

Wijayanti, Rizky Ratna, Stefanus Christian Relmasira, Janelle Lee Juneau. 2018. Penerapan Model Pembelajaran Cooperative Tipe TAI (Team Assisted Individualization) untuk Meningkatkan Hasil Belajar dan Kemampuan Berpikir Kritis Matematika. Jurnal Ilmiah Sekolah Dasar Volume 2, Number 4. 